\title{
Rusya Dış Politikası'nın Etkin Silahı: Donmuş Çatışma Bölgeleri
}

\author{
Effective Leverage of Russian Foreign Policy: \\ Frozen Conflict Zones
}

\author{
Göktürk TÜYSÜZOĞLU*
}

$\ddot{o} z$

Çok kutupluluk ekseninde bir uluslararası sistem oluşumunu arzulayan Rusya, böyle bir yapı içerisinde "küresel" bir güç olarak yer almak ve sistemin gidişatına yön veren temel aktörlerden biri olmayı istemektedir. Moskova, bunun gerçekleşebilmesi için, özelde eski Sovyet coğrafyası; genelde ise Avrasya'daki siyasal gelişmelere yön vermesi ve bu bölgede etkinliğini arttrmast gerektiğinin farkindadır. Ne var ki, uzun süre SSCB'nin bir parçası olmus ya da Doğu Bloğu içerisinde yer almuş ve yeni bağımsız olmuş bölge ülkelerini bu kez Rusya adı altında kendi siyasal ve sistemsel çıkarlarina entegre etmek oldukça güçtür. Zira Rusya ekonomik, sosyal ve siyasal nedenlerle bölge halklarıni/devletlerini rahatllkla kendisine çekebilecek bir görünüme haiz değildir. Bu nedenle, Rusya'nın realist bir eksende hareket ederek, güvenlik ve enerji bağımlılığı odakl hususlar bölge ülkeleri nezdinde kullanmaya çalıştığını görüyoruz. Ne var ki, Rusya'nın özellikle son dönemde dış politikasına eklemlediği önemli bir husus daha bulunmaktadır. Moskova, yakın çevresinde yer alan ülkelerde etnik/dinsel kimlik bağlamında ortaya çlkan ve oluşumunda SSCB döneminde çizilen sintrların önemli rol oynadığı donmuş çatışma bölgelerini, bu ülkelerin dı̧̧ politika yönelimlerini kendi çıkarları doğrultusunda manipüle edebilmek için kullanmaktadir. Hatta bu stratejinin, Kafkasya, Ukrayna ve Moldova özelinde "kendisi adına" olumlu sonuçlar doğurduğu da ortadadir.

Anahtar Sözcükler: Yeni Avrasyacıllk, çok kutupluluk, Etnik çatışma, Kırım, Abhazya, Transdinyester.

*Yrd. Doç. Dr., Giresun Üniversitesi, Uluslararası İlişkiler Bölümü,
e-posta: gktrkt@gmail.com. Geliş Tarihi / Received : 31.07.2017 Kabul Tarihi / Accepted : 18.09.2017

185

Güvenlik Stratejileri

Y11: 13

Say1: 26 


\author{
Göktürk TÜYSÜZOĞLU
}

\begin{abstract}
186
Güvenlik

Stratejileri

Y11: 13

Say1: 26

\section{Abstract}

Desiring to form an international system depending on multipolarity, Russia wants to be one of the main actors to take part in such a structure as a "global" power. In order to achieve this aim, Moscow must direct and enhance its political effectiveness at the former Soviet geography. However, it is very difficult to integrate the newly independent countries that have long been a part of the USSR or the states which were in the Eastern Bloc, into political and systemic interests of Russia. The reason for this is that Russia cannot easily attract the people/states of the region for economic, social and political reasons. For this reason, we see Russia acting as a realistic actor, trying to use the security and energy dependency of the countries in the region. However, there is another important factor that Russia has recently attached to its foreign policy. Moscow uses the "frozen conflict zones" that arise in the context of ethnic/religious identity and in which the borders drawn during the USSR to manipulate the foreign policy orientations of these countries according to its own interest. It is also true that this strategy has positive consequences for Russia in the Caucasus, Ukraine and Moldova.
\end{abstract}

Keywords: Neo-Eurasianism, multipolarity, ethnic conflict, Crimea, Abkhazia, Transnistria.

\title{
1. Giriş
}

Sovyet Sosyalist Cumhuriyetler Birliği’nin (SSCB) dağılması sonrasında Rusya, eski Sovyet coğrafyasını kendi "doğal” etki alanı olarak görmeye devam etmektedir. Sovyetler'in çöküşünün ardından bir süre ciddi sosyal, ekonomik ve siyasal krizler yaşayan ve hatta dağılabileceğine dair görüşler de ortaya konmuş olan Rusya, özellikle 1990'ların ikinci yarısında yaptığı strateji değişikliği ve milenyumun hemen ardından enerji fiyatlarında yaşanan yukarı yönlü değişim ile toparlanmış ve küresel bir güç olduğunu tüm dünyaya ilan etmiştir. Amerika Birleşik Devletleri'nin (ABD) öncülüğündeki Batı Dünyası'nın "hegemonyacı" değer aktarım girişimlerine ve uluslararası sistemi tek kutuplu bir görünüme büründürmeyi amaçlayan politikalarına genel itibarıyla karşı çıkan Moskova, Çin ile birlikte sistemsel bir "çok kutupluluk" fikrinin ardında duran en önemli aktör konumundadır. Bu nedenle, özellikle Kuzey Atlantik Antlaşması Örgütü’nün (NATO) ve bir nebze de Avrupa Birliği’nin (AB) doğuya, eski Sovyet coğrafyasına ve genel itibarıyla geniş Karadeniz havzasına doğru yaptığı veya 
Rusya Dış Politikası'nın Etkin Silahı:

Donmuş Çatışma Bölgeleri

yapmaya çalıştı̆̆ "genişleme" girişimleri Rusya tarafindan tepkiyle karşılanmaktadır.

Rusya, bu girişimlere olan tepkisini gösterebilme yönünde Sovyet mirasının kendisine sağladığı avantajları kullanmaktadır. Avrasya geneline ilişkin bilgi birikimi, sosyo-kültürel yakınlığı, ekonomik tamamlayıcılığı ve siyasal bağları, Moskova'nın kendi çevresinde yer alan eski Sovyet cumhuriyetleri özelinde en etkin ülke olmasını beraberinde getirmektedir. Üstelik Rusya, özellikle Stalin döneminde çizilen sınırlar ve "toplum mühendisliğì" girișimlerini de kendi lehine kullanmasını bilmektedir. Rusya dışında yaşayan Rus kökenlileri ya da Rusça konuşan halkları koruma ve gözetme misyonunu da 1990'lı yılların ortalarından bu yana kendine görev edinmiş olan Rusya, Batı ile rekabet içerisine girdiği Avrasya özelinde, bu avantajlarını lehine kullanmaktadır. Tabi bu hususta, AB'nin kendi içinde yaşadığı yapısal sorunlar ve Rusya'yla ilişkiler ekseninde hissedilen kafa karışıklığı ile ABD'nin Rusya'yla nasıl bir ilişki kurmak gerektiği konusunda net bir tavır gösterememesi de Moskova adına önemli bir avantaj yaratmaktadır. Hiç şüphesiz, Çin'in güçlenmesi ve etkisini arttırması da Batı Dünyası'nın Rusya ile ilişkiler bağlamında daha dikkatli ve bu ülkeyi kaybetmemeye yönelik bir tutum sergilemesine yol açmaktadır.

Donmuş çatışma bölgeleri, genel itibarıyla etnik/dinsel açıdan birbirinden farklılaşan toplumların içerisinde yaşadıkları devletlerle yaşadıkları siyasal sorunlar ekseninde ortaya çıkmakta ve çoğunlukla siyasal ayrılıkçılık talebi ya da "de facto" bağımsılılı ilanları ile sonuçlanan bir nitelik arz etmektedir. Eski Sovyet coğrafyasında bu tarz bölgelerin varlığına sıklıkla tanıklık ediyoruz. Büyük bir bölümü SSCB döneminden miras olan bu sorunların giderilmesi ya da taraflar arasında sürdürülebilir bir barış ortamının yaratılması hususunda ise coğrafi, tarihsel, sosyo-kültürel ve siyasal nedenlerle Rusya büyük bir rol oynamaktadır. Bu bağlamda, Moskova, sorunun tarafları ile etkin bir bağlantı kurmakta; gerektiğinde onlara destek olmakta ve "arka bahçesinde" yer alan ve donmuş çatışma bölgelerinin varlığından muzdarip olan ülkelerin dış politikalarını kendi istediği yönde manipüle etmeye çalışmaktadır. Dağlık Karabağ, Transdinyester, Abhazya, Güney Osetya ve 2014'ten bu yana da Donbass (Donetsk ve Luhansk) 
188

Güvenlik

Stratejileri

Y1l: 13

Say1: 26

bu bölgelerden en önemlileri olarak görülebilir.

Çalışma bağlamında öncelikle Rusya dış politikasının genel yönelimi hakkında bilgi verilecektir. Daha sonra Moskova'nın "donmuş çatışma bölgelerini" nasıl ve niçin kullandığına örnekler üzerinden değinilecek ve bu hususun Rusya'nın özellikle Bat1 ve diğer küresel aktörlerle ilişkilerini nasıl etkilediği hakkında çözümlemeler yapılacaktır.

\section{Rusya Dış Politikası’nın Konjonktürel Görünümü}

SSCB'nin dağılması sonrası ciddi kafa karışıklığı yaşayan, 1990'ların ilk yarısında "parçalanabileceği” dahi konuşulan ve özellikle Çeçenistan'daki bağımsızlık mücadelesi ekseninde bunun gerçekleşebileceğine dair analizler yayınlanan Rusya, ${ }^{1}$ bugün itibarıyla "saygın" bir küresel güç olarak sistemdeki yerini almış durumdadır. SSCB sonrası yaşanan krizin temelinde, ülkenin yeni dönemde ne tür bir ekonomik ve siyasal dönüşüm yaşayacağı, hangi değerleri içselleştireceği ve özellikle de Batı'yla ilişkiler bazında nasıl bir tavır göstereceği gibi hususlar yer almaktaydı. İlk etapta Batı'nın hegemonyasını kabullenme ve ona entegre olma yönünde hamleler yapan Moskova, ekonomik/siyasal dönüşüm sürecinde özellikle Washington'dan "samimi" ve yeterli bir destek göremeyince zor bir durumda kalmıştır. Çeçenistan'ın bağımsızlık mücadelesinin Batılı aktörlerce samimi bir tonda karşılanması, ${ }^{2}$ eski Sovyet coğrafyasındaki etkinliğinin göz ard1 edilmek istenmesi, piyasa ekonomisine geçiş ve liberal siyasal değerlerin içselleştirilmesi hususunda baskı yapılması gibi faktörler, SSCB döneminde sahip olunan "küresel" etkinliğin tamamen kaybedilmek üzere olduğuna ilişkin bir algı yaratmıştır. Üstelik Rusya'nın zayıf bir aktör haline getirilmek istendiğine ilişkin algının yaratılmasında payı olan temel unsur da Rusya'nın eklemlenmeye çalıştığı Batı Dünyası ve özelde de ABD olmuştur. Bu algı, Ruslar, özellikle de Rus siyasal/askerî

${ }^{1}$ Olga I. Vendina, Vitaliy S.Belozerov and Andrew Gustafson, "The Wars in Chechnya and Their Effects on Neighboring Regions", Eurasian Geography and Economics, Vol. 48, No. 2, 2007, pp. 178-201.

2 Dmitri V. Trenin, “The Forgotten War: Chechnya and Russia's Future", Carnegie Endowment Policy Brief, No. 28, Kasim 2003. 
elit tabakası arasında Batı'ya ilişkin "şüpheci” tutumun konsolide olmasına neden olduğu gibi; ülke içinde yaşayan farklı etnik/dinsel kimliğe haiz toplumları da kendi geleceklerinin Rusya içerisinde olmayabileceğine dair bir anlayışa itmiştir. ${ }^{3}$

Güvenlik

Stratejileri

Bu minvalde, 1990'ların ortalarından itibaren Kozyrev'in Batı hegemonyasını itirazsız kabul etme yönünde izlediği dış politika anlayıșının terk edildiğini ve Rusya'yı bulunduğu coğrafyada öncü aktör rolünü içselleştirmeye yönlendiren Avrasyacı anlayışın Atlantikçiliğin yerine ikame edildiğini görüyoruz. Avrasyacılık, kökeni 1920'lere kadar giden ve çeşitli görüşlerle zenginleştirilip kavramsal bir arka plana kavuşturulmak istenen bir anlayışa işaret etse de; temelde Rusya için bir "kriz" ideolojisidir. ${ }^{4}$ Nitekim Rusya'nın krizde olduğu bir zaman diliminde yeniden yükselişe geçmiş ve Moskova'nın siyasal anlayışını ve dış politikada izleyeceği rotayı biçimlendirmiştir. Esasen bir imparatorluk stratejisine işaret eden Avrasyacılık; Rus kimliğini, Avrasya coğrafyasına, tarihine ve kültürüne içkin bir "üst benlik" olarak kurgulamakta ve Rus Çarlığı ile SSCB döneminde Moskova'nın kontrolünde olan "Avrasya" anakarasında yaşayan tüm toplumların, etnik/dinsel kimliklerinden bağımsız olarak, Avrasya medeniyetine ait olduklarını ifade etmektedir. ${ }^{5} \mathrm{Bu}$ anlayış çerçevesinde, Rus kimliği, Slavofillerin öngördüğü etnik/ulusal içeriğinden soyutlanmakta ve Avrasyalı kimliği ile eşlenerek bir "üst kimlik" olarak Rusyalı-Avrasyalı haline getirilmektedir. Avrasyacılar, Rus olmayı, var olduğunu belirttikleri Avrasya medeniyetinin bileşkesi olarak görmekte ve etnik/dinsel çerçevede yaşamaya devam edecek "alt kimliklerin" ötesinde bir "üst/medeniyetsel aidiyet” olarak şekillendirmektedir. Avrasya'nın

${ }^{3}$ James Hughes, "Managing Secession Potential in the Russian Federation”, Regional \& Federal Studies, Vol. 11, No. 3, 2001, pp. 36-68.

${ }^{4}$ Anatoly M.Khazanov, "A State without a Nation? Russia after Empire", The Nation State in Question, T. V. Paul, G. John Ikenberry and John A.Hall (ed), New Jersey: Princeton University Press, 2003, p. 82.

${ }^{5}$ Natalia Morozova, "Geopolitics, Eurasianism and Russian Foreign Policy Under Putin”, Geopolitics, Vol. 14, No. 4, 2009, pp. 667-686. 
190

Güvenlik Stratejileri

Y11: 13

Sayı: 26

coğrafi sınırları ise Rus Çarlığı ve SSCB dönemleri çerçevesinde çeşitli anlamlandırmalara konu olmaktadır. Ancak genel itibarıyla "klasik" Avrasyacıların öngördüğü Çarlık sınırları kabul görmektedir. Rus ulusçuluğunu geri plana iterek "çok etnikli/dinli" ortak bir medeniyet kimliğinin altını çizen Avrasyacılık, bu anlayışı Avrasya medeniyetinin sahip olduğu belirtilen devlet aygıtına bağlılık, otoriter yönetim kalıpları, korporatizm ve bireycilik karşıtı anlayış ile güçlendirmektedir. Doğu Hıristiyanlığına ve özelde de Avrasya'ya entegre bir dini anlayış olan Ortodoksluk ile yine Avrasya anakarasının bir parçası olan İslam arasındaki ittifak da Rusya'nın siyasal anlayışına ve dış politikasına etki eden Avrasyacıllı̆ı̆ önemli bileşenlerindendir. ${ }^{6}$ Neo-Avrasyacılar ise Dugin önderliğinde Avrasyacıllğa "jeopolitik" bir ekleme yapmıştır. $\mathrm{Bu}$ çerçevede, Avrasyacılığın temel yönelimleri kabul edilmekle birlikte, ABD'nin önderliğindeki Atlantik Dünyası'na karşı çıkan ve onun hegemonyasını reddeden her aktör Avrasya ile iş birliği içerisinde görülmüştür. Hatta Dugin'in, Batı içinde de bir ayrıma gittiğini ve ABD ile İngiltere'ye şiddetle karşı çıkarken; Kıta Avrupası'nın lider ülkeleri Almanya ve Fransa'yı iş birliği yapılması gereken aktörler olarak gördüğünü biliyoruz. ${ }^{7}$

İşte, Rusya, 1990'ların ortalarından itibaren bu anlayışa yaslanan bir dış politika yönelimine sahip olmuştur. Pragmatik bir çerçevede inşa edilen bu yaklaşım, yerine göre Batı ile iş birliğine gitse ve söylemde de bunu yansitsa da; genel itibarıla tutarlı bir görünüm arz etmiştir. $\mathrm{Bu}$ çerçevede, ilan edilen "yakın çevre doktrini"» ile Rusya'nın eski Sovyet coğrafyası ve Doğu Bloğu ülkeleri ekseninde "özel” bir nüfuzu olması gerektiği ve bu ülkelerin dış politika algılarının Moskova ile olabildiğince uyumlu bir bağlamda şekillenmesi gerektiği; gerek bu

${ }^{6}$ Dmitry Shlapentokh, "Islam and Orthodox Russia: From Eurasianism to Islamism", Communist and Post-Communist Studies, Vol. 41, Mart 2008, pp. 27-46.

7 Anton Shekhovtsov, “Aleksandr Dugin's Neo-Eurasianism: The New Right a la Russé”, Religion Compass, Vol. 3, No. 4, 2009, pp. 697-716.

${ }^{8}$ Marléné Laruellé, "The Russian World: Russia's Soft Power and Geopolitical Imagination”, CGI-Center on Global Interests, Mayıs 2015. 
Rusya Dış Politikası'nın Etkin Silahı:

Donmuş Çatışma Bölgeleri

ülkeler, gerekse de $\mathrm{ABD}$, NATO ve $\mathrm{AB}$ nezdinde kabul ettirilmeye çalışılmıştır. Ayrıca, bu coğrafyada yaşayan Ruslar ve Rusça konuşanların haklarının savunulması hususunda Moskova'nın her daim ön planda olacağı gösterilerek, gerektiği takdirde, bu ülkelerin içişlerine de karışılacağı ortaya konmuştur. Bu minvalde, Rusya, yakın çevresi olarak gördügü ve "arka bahçe" olarak da adlandırılan eski Sovyet coğrafyasına ilişkin olarak NATO ve AB'nin birbirlerine paralel olarak gerçekleştirdiği genişleme dalgalarına genel itibarıyla eleştirel yaklaşmışırı. Jeopolitik bağlamın altını önemle çizen Yeni-Avrasyacı retoriğin, $A B D$ ve İngiltere'nin önderliğini yaptığı Atlantik Dünyası'na karşı Kıta Avrupası'nı müttefik olarak yapılandırmak istemesi, Rusya'nın AB'ye daha itidalli yaklaşmasına ve tepkisini genel itibarıyla Atlantikçiliğin esas "Truva atı" olarak gördüğü NATO'ya yönlendirmesine neden olmuştur. ${ }^{9}$ Dugin, AB'nin zamanla ABD'den uzaklaşabileceğini ve Rusya'nın da Kıta Avrupa'sı ile iş birliği yaparak Atlantikçi eğilimi baskılayabileceğini ifade etmektedir.

Milenyum sonrası dönemde Rusya Dış Politikası'nda “çok kutupluluk" yanlısı eğilimin belirgin hâle geldiğini ve bunun Vladimir Putin tarafindan da açikça ortaya konduğunu biliyoruz. ${ }^{10}$ Çeçenistan'daki mücadelenin kazanılması, federasyonun dağılabileceğine ilişkin söylentileri perdenin gerisine itip, dünya enerji fiyatlarının yükselmesi ekonomik konsolidasyonu sağlayınca, Avrasyacılığın öngördüğü otoriter yönetimsel kalıpları inşa eden Putin ve ekibinin eli güçlenmiştir. Tabi Rusya'nın bu eğilimi "güçlü" bir şekilde yansıtabilmesi noktasında önemli bir dayanağı da ekonomik gücüne paralel olarak müthiş bir yükseliş gösteren Çin olmuştur. Rusya ile Çin'in, Birleşmiş Milletler (BM) Güvenlik Konseyi başta olmak üzere tüm uluslararası örgütlerde

\footnotetext{
${ }^{9}$ James Greene, "Russian Responses to NATO and EU: Enlargement and Outreach", Chatham House Russia and Eurasia Programme Briefing Paper, Haziran 2012.

${ }^{10}$ S.Frederick Starr and Svante E.Cornell, "Tactics and Instruments in Putin's Grand Strategy", Putin's Grand Strategy: The Eurasian Union and Its Discontents, S.Frederick Starr and Svante E.Cornell (ed.), Washington: Silk Road Studies, 2014, pp. 59-81.
}

Güvenlik Stratejileri

Y11: 13

Sayı: 26 

Batı hegemonyasına karşı çıkması önemli bir sistemsel başkaldırı haline gelmiştir. ${ }^{11} \mathrm{Bu}$ duruş, ABD başta olmak üzere, Batılı aktörlerin etkinliğini önemli oranda sınırladığı gibi, Batılı siyasal/toplumsal değerlerin aktarım sürecini de ciddi anlamda yavaşlatmış ve farklı anlayışların kendisini ortaya koyması ya da korumaya alması hususunda önemli bir uyarıcı olmuştur. Rusya, özellikle 2008 yılında Gürcistan'a yaptığı askerî müdahale, 2014 yılında başlayan Ukrayna Krizi ve ardından gelen Kırım'ın ilhakı ile Suriye'deki iç savaşa doğrudan müdahalesi sonrası, söylem bazında kalan "edilgen" duruşunu terk ettiğini ve "etken" bir aktör olarak yakın çevresinde ve hatta önemli çıkarlarının olduğu bölgelerde/ülkelerde askerî ve siyasal güç kullanacağını açıķa ortaya koymuştur. Böylece söyledikleri dikkate alınması gereken küresel bir aktör olduğunu hem Rusya halkına kanıtlayıp toplumsal/siyasal konsolidasyonu arttırarak Batı yanlısı muhalefeti etkisiz kılmış; hem de başta ABD olmak üzere Atlantik Dünyası'na açık bir mesaj vererek "hegemonya" inşası girişiminin başarısız olacağını kanıtlamaya çalışmıştır. Bu duruş, $\mathrm{AB}$ içinde dahi Rusya'ya ilişkin tutum noktasında ABD'yle birlikte hareket edilip edilmemesi bağlamında sorgulamalara neden olurken; ${ }^{12}$ İran başta olmak üzere birçok bölgesel aktör Rusya'nın yanında yer almış, NATO üyesi Türkiye dahi belli hususlarda Rusya'ya daha yakın bir duruş sergilemeye başlamıştır. ${ }^{13}$ Hiç şüphesiz, bu durum Rusya adına olumlu bir görünüm yaratmaktadır.

\section{Rusya'nın Donmuş Çatışma Böıgelerine Olan Yaklaşımı}

Atlantikçi sistemsel hegemonyanın aşılabilmesi yönünde çok kutupluluğu önemli bir hedef olarak gören ve bu bağlamda jeopolitik

${ }^{11}$ Susan Turner, "Russia, China and a Multipolar World Order: The Danger in the Undefined", Asian Perspective, Vol. 33, No. 1, 2009, pp. 159-184.

12 E.Wayne Merry, "Dealing with the Ukrainian Crisis: Transatlantic Strategy Dilemmas", IAI Working Papers, Vol. 15, No. 51, 2015.

13 Aslı Aydıntaşbaş and Kemal Kirişci, "The United States and Turkey: Friends, Enemies or Only Interests", Brookings Institute Turkey Project Policy Paper, No. 12, Nisan 2017. 
unsurların altını çizerek Avrasya genelini Rusya'nın siyasal, ekonomik ve sosyo-kültürel hegemonyası çerçevesinde kurgulamaya çalışan Yeni Avrasyac ${ }^{14}$ bir dış politika anlayışına yaslanan Moskova, bu minvalde "yakın çevresine" büyük önem atfetmektedir. Yakın çevresi olarak gördüğü esas alan ise "eski Sovyet toprakları" olarak bilinen ülkelerdir. Nitekim Rusya, Balkanlar geneli ile Orta Avrupa özelindeki Batı etkinliğinin orta vadede kırılmayacak denli kurumsallaştığını görmektedir. Moskova'nın hedefi, Doğu Avrupa, Karadeniz-Kafkasya ve Hazar-Orta Asya bölgelerinde konumlanmış ve diş politika alternatifi anlamında henüz açık bir tercihte bulunmamış ya da Batı hegemonyasına henüz tamamıla entegre edilmemiş ülkeleri kendi yanına çekebilmek ya da kontrol altında tutabilmektir. Rusya, ortaya koyduğu çok kutupluluk anlayışının kurumsallaşabilmesi ve kendini de küresel bir güç olarak yapılandırabilmesi için Avrasya genelinde "hegemonya" oluşturması ve güç temerküzüne gitmesi gerektiğinin bilincindedir. Üstelik tarihsel, sosyo-kültürel, ekonomik ve siyasal faktörler de bunu kolaylaştırabilecek bir mahiyet de arz etmektedir.

Rusya'nın yakın çevresine etki edebilme anlamında kullanabileceği önemli bir "yumuşak güç" unsuru bulunmamaktadır. ${ }^{15}$ Zira otoriter yönetim kalıpları, insan haklarına dair sorunlu sicili, Çarlık ve Sovyet dönemlerine ilişkin olumsuz toplumsal/siyasal alg1 ve düşük toplumsal refah düzeyi, Moskova'nın "yumuşak güç" kullanımı anlamında etkisiz kalmasına yol açmaktadır. Bu nedenle, yakın çevresi bağlamında hegemonya oluşumu anlamında askerî güç unsurları ve siyasal zorlama yöntemlerinin Kremlin tarafından sıklıkla kullanıldığı görülmektedir. Rusya, bu yöntemleri özellikle NATO’nun “doğuya” yani eski Sovyet coğrafyasına yönelttiği genişleme dalgalarına karşı ve yine özellikle ABD'nin Orta Asya-Hazar Bölgesi'nde yer alan ülkelerle olan temasını

14 Andreas Umland, "Post-Soviet Neo-Eurasianism, the Putin System and the Contemporary European Extreme Right", Perspectives on Politics, Vol. 15, No. 2, 2017, pp. 465-476.

${ }^{15}$ Alexander Sergunin and Leonid Karabeshkin, "Understanding Russia's Soft Power Strategy", Politics, Vol. 35, No. 3-4, 2015, pp. 347-363. 
194

Güvenlik Stratejileri

Y1l: 13

Sayı: 26 en alt düzeye indirgeyebilmek için kullanmaktadır. Rusya'nın yakın çevresi ya da arka bahçesi olarak gördügü coğrafi alandaki ülkeleri kendi yanına çekebilmek ya da kendi bölgesel çıkarlarına zarar verebilecek hamlelerde/seçimlerde bulunmaktan uzak durmaya yönlendiren siyasal baskı araçlarından biri de "donmuş çatışma bölgeleri"nin istenen yönde manipüle edilmesi ya da kullanılmasıdır. ${ }^{16}$

Eski Sovyet coğrafyasında yer alan ve bugün bağımsızlığına kavuşmuş olan birçok ülke etnik/ulusal açıdan homojen olmaktan uzaktır. SSCB döneminde çizilen içsel sınırlar çerçevesinde bağımsızlık ilanları geldiği için, o dönemde idari/siyasal gereklilikler nedeniyle yanlış çizilmiş sınırlar ekseninde aynı devletin sınırları içinde kalmış, ancak kimlik tabanında birbirinden ayrılan ve rekabet içinde olan halklar birbirleriyle sorun yaşamaya başlamıştır. ${ }^{17} \mathrm{Bu}$ sorun da genel itibarıyla iç savaş, siyasal ayrılıkçılık ya da özerklik talepleri ile sonuçlanan bir mahiyet arz eder hale gelmiştir. Yani çok uluslu bir görünüme sahip olan ya da azınlık düzeyinde de olsa farklı kimlikleri içinde barındıran eski Sovyet cumhuriyetleri, tarihsel, sosyo-kültürel ve pek tabi ki siyasal nedenlerle birbirleriyle sorun yaşamaya başlamışlardır. SSCB döneminde ideolojik baskı, otoriter yönetim kalıpları ve sistemsel çift kutupluluğun yapısal özellikleri çerçevesinde geri plana itilmiş olan bu meseleler; SSCB'nin dağılması ve yeni devletlerin kurulması sonras kanlı çatışmalar ve ayrılıkçı hareketlilikler bağlamında uluslararası politikanın gündemine girmiştir. Yeni bağımsızlaşmış eski Sovyet cumhuriyetlerinin demokratik gelişim düzeyi ile sosyo-ekonomik refah düzeyinin oldukça düşük kalması ve merkezi yönetimin sert güç kullanma yönündeki istekliliği; yeni bağımsızlı̆̆ın beraberinde getirdiği "yükselen ulusçuluk" dalgasıyla birleştiğinde, büyük çaplı kimlik bunalımları yaşanmış ve bunlar silahlı çatışmalara dönüşüp,

${ }^{16}$ Robert Orttung and Christopher Walker, "Putin's Frozen Conflicts", Foreign Policy, 13 Şubat 2015, http://foreignpolicy.com/2015/02/13/putins-frozen-conflicts, (Erişim Tarihi: 24.07.2017).

${ }^{17}$ Brittany A.Pohl, "Frozen Conflicts, De Facto States and Enduring Interests in the Russian near Abroad", MSU Graduate Theses, No. 3039, 2016. 
birçok örnekte "donmuş çatışma bölgeleri" olarak siyasal arenaya yansımıştır. İşte, bu sorunlar özelinde çatışmayı durdurma, tarafları diyaloga yönlendirme ve çözüm önerileri ortaya koyma hususunda ön plana çıkan aktör de Rusya olmuştur. ${ }^{18}$ Zira Moskova, kendisinden Güvenlik Stratejileri kopan ülkelerde yaşanan sorunlar ve bu sorunların tarafları hakkında ciddi bilgi birikimine sahiptir. Ayrıca coğrafi yönden sahip olduğu avantaj ve askerî gücü de Rusya'nın "arka bahçesinde" beliren donmuş çatışma bölgeleri özelinde inisiyatif almasında etkili olmuştur. Rusya, donmuş çatışma bölgelerinin varlığı çerçevesinde, bahsedilen ülkelerin içişlerine karışma firsatı elde etmiş; kendi dış politik çıkarları ekseninde ayrılıkçı güçleri ya da bahsedilen devletlerin hükümetlerini (askerî, lojistik ya da ekonomik yönden) gizlice desteklemiş ve bu ülkelerin/halkların geleceklerini kendi çıkarları bağlamında manipüle ederek Avrasya anakarasında en etkin güç olduğunu/olacağını ispatlamaya çalışmıştır.

Tabi bu çerçevede Rusya'nın göz önünde bulundurması gereken önemli bir husus, kendisinin de benzer sorunlar yaşamış ve yaşama ihtimali olan bir ülke olduğudur. Bu nedenle, Moskova uzun süre oldukça ihtiyatlı davranmıştır. Federal bir yapıyı haiz ve içinde çok farklı etnik ya da dinsel kimliklerden gelen halkları barındıran Rusya, 1990'lı yıllar boyunca süren ve Çeçenistan özelinde fiili bir nitelik de kazanan siyasal ayrılıkçılık ve dağılma psikozunu tam manasıyla aşabilmiş değildir. ${ }^{19}$ Merkezi yönetimin gücünü arttırabilmek için federe birimlerin etkinliğini sınırlayan adımlar atılmış ve otoriter bir devlet yapılanmasına eklemlenilmiş olmasına karşın, başta Kuzey Kafkasya ve Tataristan olmak üzere birçok bölgenin geleceğine ilişkin soru işaretleri Kremlin'de kapalı kapılar ardında tartışılmaktadır. ${ }^{20}$ Ancak Moskova, içe dönük

\footnotetext{
${ }^{18}$ Liam Stack and Karen Zraick, "Frozen Zones: How Russia Maintains Influence in the Post Cold War Era", The New York Times, 14 Ekim 2015, https://www.nytimes.com/interactive/2015/10/14/world/europe/russia-frozen-zonessyria.html (Erişim Tarihi: 24.07.2017).

${ }_{19}$ Mike Bowker, "Russia and Chechnya: the Issue of Secession", Nations and Nationalism, Vol. 10, No. 4, 2004, pp. 461-478.

${ }^{20}$ James Hughes, "Managing Secession Potential in the Russian Federation", Regional \& Federal Studies, Vol. 11, No. 3, 2001, pp. 36-68.
} 


\section{Göktürk TÜYSÜZOĞLU}

196

Güvenlik Stratejileri

Y1l: 13

Sayı: 26

savunmacı tedbirler almayı bırakarak "bölgesel bir hegemonya" kurabilmeyi ve kendi çıkarlarını ve hatta toprak bütünlügünü ülke sınırları dışında, eski Sovyet coğrafyası özelinde koruyabilmeyi hedeflemektedir. Bu çerçevede de, hem yakın çevresinde yer alan ülkelerin dış politikalarını Moskova'nın talepleri bağlamında kurgulayabilmek, hem de bu ülkelerle kendi sistemsel etkinliğini Avrasya geneline yayabilmek için donmuş çatışma bölgelerinin yarattığı belirsizlik ve sorunları kendi lehinde kullanmayı amaçlamaktadır.

Moskova'nın kendi dış politikasına içkin olarak kullandığ1 donmuş çatışma bölgelerinden bazıları aşağıda açıklanmışıır.

\subsection{Dağlık Karabăg}

Ermenistan'in bölgede sürdürdüğü işgal, Rusya'nın Güney Kafkasya özelindeki en önemli dayanak noktalarından birini oluşturmaktadır. Bilindiği üzere Ermenistan, Dağlık Karabağ ve çevresinde yer alan yedi rayonu işgal etmiştir ve 25 yıla yakın bir süredir bu sorun çözülememektedir. ${ }^{21}$ İşgal esnasında, doğrudan değil ama dolaylı yollardan bölgede konumlanmış olan bazı Sovyet birliklerinin Ermeni Ordusu'na destek verdiği de bilinmektedir. ${ }^{22}$ Rusya, Dağlık Karabağ Meselesi'nin bir ateşkese kavuşturulması hususunda doğrudan inisiyatif almış ve bu anlamda başarılı olarak sorun ekseninde meşru bir dışsal aktör olarak kendini kabul ettirmiştir. Aynı zamanda Avrupa Güvenlik ve İş Birliği Teşkilatı (AGIT) bünyesinde sorunu halledebilmek için oluşturulmuş olan Minsk Grubu'nun üç üyesinden (diğerleri ise ABD ve Fransa'dır) biri olan Rusya, ${ }^{23} 1994$ yılından bu yana Dağlık Karabağ meselesini kendi çıkarları ekseninde kullanmaktadır. Nitekim Moskova'nın, sorunun tarafı pozisyonunda olan her iki ülkeye de

${ }^{21}$ Araz Aslanlı, “20.Yüzyılın Başlarında ve Sonlarında Güney Kafkasya'da Ermeni Sorunu: Karabağ Sorunu Örneği”, Yeni Türkiye, No. 60, 2014, pp. 1-24.

${ }^{22}$ Shamkhal Abilov and Ismayil Isayev, "The Consequences of the Nagorno-Karabakh War for Azerbaijan and the Undeniable Reality of Khojaly Massacre", Polish Political Science Yearbook, Vol. 45, 2016, pp. 296.

${ }^{23}$ Vladimir Kazimirov, Peace to Karabakh: Russia's Mediation in the Settlement of the Nagorno-Karabakh Conflict, Moscow: VES MIR Publishers, 2014. 
Rusya Dış Politikası'nın Etkin Silahı:

Donmuş Çatışma Bölgeleri

büyük miktarlarda silah sattığı bilinmektedir. Gerek Ermenistan gerekse de Azerbaycan bu silahları öncelikle Dağlık Karabağ meselesi ekseninde çıkan ya da çıkması muhtemel askerî çatışmalarda birbirlerine üstünlük sağlamak için almaktadır. Ancak görüldügü üzere, sorun devam ettikçe Rus silah sanayi oldukça kârlı bir pazara kavuşmuş olmaktadır. Ayrica Rusya, bu sorun ekseninde hem Azerbaycan'ın hem de Ermenistan'ın dış politikalarını istediği yönde manipüle edebilmektedir. Azerbaycan'ın Batı ve Türkiye ile geliştireceği ilişkiler, enerji stratejisi ve Rusya'ya yönelik yaklaşımı genel itibarıyla Dağlık Karabăg meselesi özelinde şekillenmektedir. Zira Rusya, Bakü'nün kendisine ciddi zarar verebilecek bir rotaya girmesi halinde, sorunun Ermenistan lehinde çözümlenmesi yönünde çaba göstereceğini Azerbaycan Hükümeti'ne çeşitli yollardan göstermektedir. Benzer durum Ermenistan için de geçerlidir. Hatta Rusya'nın Ermenistan üzerindeki etkisinin Azerbaycan'a oranla çok daha fazla olduğu söylenebilir. Zira Rusya, nüfusu sürekli azalan ve ekonomik olarak çok zor durumda olan Ermenistan'ın savunma, enerji ve hatta ekonomik ihtiyaçlarının giderilmesinde çok önemli bir rol oynamaktadır. Ermenistan topraklarında bir hava (Erivan/Erebuni), bir kara üssü (Gümrü) bulunan, ülkenin nükleer santralini (Metsamor) işler halde tutan ve enerji ihtiyacının çok büyük bir bölümünü karşılayan Moskova, ülke ekonomisine yön veren pek çok şirketin de sahibidir. ${ }^{24}$ Üstelik Ermenistan, Rusya'nın Avrasya özelinde Moskova merkezli bir bölgesel hegemonya kurgulama girişimi olarak bilinen Avrasya Ekonomik İşbirliği Örgütü (AEIÖ) ve onun askerî uzantısı olarak görülebilecek Kolektif Güvenlik Antlaşması Örgütü (KGAÖ) gibi kurumsal yapılara üye olan tek Güney Kafkas ülkesidir. ${ }^{25}$ $\mathrm{Bu}$ bağlamda, Rusya'nın Dağlık Karabağ meselesi özelinde de Ermenistan'ın ayakta kalmasını ve işgali sürdürebilmesini sağlayan en önemli aktör olduğu rahatlıkla anlaşılabilir. Hatta iki ülke arasında

\footnotetext{
${ }^{24}$ Ilgar Gurbanov, "Is Armenia a Strategic Satellite of Russia?", New Eastern Europe, Vol. 8, No. 3, 2013, pp. 82-88.

${ }^{25}$ Konrad Zasztowt, "Armenia in the Eurasian Economic Union: Challenges for the EU”, PISM Bulletin, No. 22 (754), 2015.
}

Güvenlik Stratejileri Y11: 13

Say1: 26 

verilebilmesini sağlayabilmek amacıyla, ortak bir askerî görev gücü oluşturulması yönünde bir çaba da vardır. ${ }^{26}$ Rusya ve Ermenistan'ın "ortak ordu" kuracağına ilişkin söylentiler de kulislerde yankılanmaktadır.

Rusya, Güney Kafkasya'daki etkinliğini sürdürebilmesi anlamında adeta bir "kale" görüntüsü veren Ermenistan'ın dış politika yaklaşımını değiştirmesini engelleyebilmek için, tüm bu faktörlerin yanı sıra, Erivan'1 Dağlık Karabağ özelinde verdiği diplomatik, stratejik ve hatta askerî desteği kesmekle tehdit edebilir. Yani Ermenistan, Rusya'ya tam bağımlı bir görüntü içinde olmakla birlikte, Dağlık Karabağ ve çevresindeki işgali sürdürebilmesi için buna "zorunlu" olduğu düşüncesi içindedir. Rusya'nın Ermenistan'dan çok daha güçlü ve gelişmiş bir görünümü haiz olan Azerbaycan'a destek vermesi ya da Azerbaycan Ordusu'nun işgali sonlandırmak için yapacağ 1 herhangi bir müdahale karşısında tarafsız kalması, Ermenistan'ın muhtemelen Dağlık Karabağ' 1 kaybetmesi ile sonuçlanacaktır.

\subsection{Abhazya ve Güney Osetya}

Rusya'nın "donmuş çatışma bölgelerini” kendi dış politikası lehinde kullanma girişimi, en açık örneğini bu iki bölge özelinde vermiştir. Nitekim her iki bölge de, tıpkı diğer donmuş çatışma bölgeleri gibi uzunca süre Rusya tarafindan siyasal bağlamda "sürüncemede" bırakılmış; ancak son kertede, Moskova, bu bölgelerin kendisi açısından "bağımsız" birer devlet olduğunu ilan ederek kendi dış politika stratejisi ekseninde çarpıcı bir adım atmıştır. ${ }^{27}$

Bilindiği üzere Abhazya ile Güney Osetya, sosyo-kültürel ve etnik anlamda Gürcü ulusal kimliğinden farklı bir bağlama sahip olmalarına karşın, SSCB döneminde Gürcistan'a bağlanmış ve biri özerk

26 "Rusya'dan Ermenistan'la Ortak Orduya Onay Çıktı", Kırım Haber Ajansı (QHA), 16 Temmuz 2017, http://qha.com.ua/tr/askeri-guvenlik/rusya-dan-ermenistan-la-ortakorduya-onay-cikti/157530 (Erişim Tarihi: 25.07.2017).

27 Brian J.Ellison, "Russian Grand Strategy in the South Ossetia War", Demokratizatsiya, Vol. 19, No. 4, 2011, pp. 343-366. 
Rusya Dış Politikası'nın Etkin Silahı:

Donmuş Çatışma Bölgeleri

cumhuriyet (Abhazya), diğeri ise özerk bölge (Güney Osetya) olarak teşkilatlandırılarak Tiflis' in hükümranlığına bırakılmış bölgelerdir. ${ }^{28}$ Gürcistan SSCB döneminde var olan sınırlar özelinde bağımsızlığını ilan ettiği için, her iki bölgenin statüsü de aynen sürdürülerek bağımsız Gürcistan Cumhuriyeti'ne devredilmiştir. Ne var ki, SSCB döneminde büyük bir soruna yol açmayan bu durum, SSCB'nin dağılması, bağımsızlık süreci ve Gürcistan özelinde yükselen Gürcü ulusçuluğu ekseninde ciddi krize neden olmuştur. Nitekim Gamsakhurdiya'nın "Gürcistan, Gürcülerindir" şeklinde betimlediği yeni siyasal anlayış, ülke içindeki farklı etnik/dinsel gruplar özelinde endişeye yol açmışırı. ${ }^{29}$ Bu bağlamda, zaten öteden beri Gürcistan'a bağlı olmamaları gerektiğini düşünen Abhazya ile Güney Osetya'da da Abhaz ve Oset ulusçulukları yükselişe geçmiştir. Bu minvalde, Tiflis ile bu bölgeler özelindeki anlaşmazlık kısa sürede silahlı çatışmalara ve iç savaşa dönüşmüş; çok sayıda insan hayatını kaybederken Gürcistan'ın bu bölgeler özelindeki "fiili" egemenliği kaybolmuştur. Rusya, bu mücadele ekseninde Abhazya ve Güney Osetya'ya daha yakın durmuş ve sonrasında da Tiflis ile Sohum ve Tskhinvali arasında ateşkes yapılmasında başat rol üstlenmiştir. Bölgeye barış gücü adı altında asker yerleştiren Rusya, Abhazya ile Güney Osetya'da askerî üslere de sahip olmaya devam etmiştir. $^{30}$

Mikhail Saakaşvili döneminde Rusya ile bağlarını tamamen kopararak NATO ve AB üyeliği ekseninde bir diş politika izleyen ve Akhalkalaki'deki Rus askerî üssünün de kapanmasını sağlayan Tiflis, bu minvalde Moskova ile çok ciddi bir gerginlik yaşamaya başlamıştır. ${ }^{31}$

\footnotetext{
${ }^{28}$ Vladimir Kolossov and John O'Loughlin, "Violence in the Caucasus: Economic Insecurities and Migration in the De Facto States of Abkhazia and South Ossetia", Eurasian Geography and Economics, Vol. 52, No. 5, 2011, pp. 1-30.

${ }^{29}$ Argun Başkan, "Kafkasya'da Bütünleşme ve Dağılma Döngüleri İçinde Gürcüler, Zanlar (Megreller ve Lazlar) ve Svanlar”, Karadeniz Araştırmaları, No. 30, 2011, pp. 34.

${ }^{30}$ Dennis Sammut and Nikola Cvetkovski, Confidence Building Matters: The Georgia-South Ossetia Conflict, London: VERTIC Papers, 1996.

31 Indra Overland, "The Closure of the Russian Military Base at Akhalkalaki:
} 


\section{Göktürk TÜYSÜZOĞLU}

200

Güvenlik

Stratejileri

Y1l: 13

Sayı: 26

Rusya yanlısı Aslan Abaşidze'yi ülkeyi terk etmeye zorlayarak Acaristan'ın özerkliğini anlamsızlaştıran ve bu anlamda merkezi yönetimi de güçlendiren Saakaşvili, Batı'dan gelecek desteğe de güvenerek Putin'i ve Rusya'yı her yönden eleştirmiş; ülkesinin özellikle NATO üyesi olacağının altını sürekli çizmiştir. Ayrıca Acaristan Sorunu'nu çözdükten sonra Abhazya ile Güney Osetya'y1 Tiflis' in egemenliğini kabul etme yönünde baskılamaya başlamıştır. Bu girişim, her iki bölgenin ve ateşkesin garantörü olan Rusya'nın, Gürcistan'ın Güney Osetya'ya askerî müdahalede bulunmaya kalkışması sonrası Ağustos 2008'de, Gürcistan topraklarına asker sokması ve iki ülke arasında beş günlük bir savaşın yaşanmasına neden olmuştur. ${ }^{32}$ Gürcü Ordusu Rus kuvvetleri karşısında tutunamayınca, Batılı ülkelerin de girişimiyle Rusya müdahaleyi durdurmuştur. Ne var ki, bu harekât sonrasında her iki bölgedeki Rus nüfuzu daha da artmış; aynı yıl içinde Moskova, her anlamda kendine bağımlı olan bu iki bölgeyi "bağımsız" birer devlet olarak tanıyarak onlara güvenlik garantisi veren anlaşmalar imzalamıştır. Gürcistan ise, bu durumu kabullenmemiş ve Rusya'yı içişlerine karışan saldırgan bir devlet olarak tanımladığı gibi, Batı yanlısı tutumunu da değiştirmemiştir. Ne var ki, NATO'nun, bu gelişme sonras1, Gürcistan'ın üyeliği konusunu geri plana ittiği görülmüştür. Rusya'nın tepkisi, NATO müttefiklerinde ve $\mathrm{AB}$ içinde ciddi bir tedirginlik yaratmıştır. Saakaşvili'den sonra (2013 sonrası) iktidara gelen Gürcistan hükümetleri de NATO üyeliğini hemen hiç dillendirmemiş; ancak $\mathrm{AB}$ ile olan yakınlaşmaya önem vermeye devam etmiştir.

Rusya'nın bu tutumu, donmuş çatışma bölgelerini bir "koz" olarak kullanmayı diş politika stratejisi olarak gören bu ülkenin gerektiği takdirde bu bölgeleri koruyup, onların statülerini olabilecek en üst seviyede kurgulayabileceğini kanıtlamaktadır. Her ne kadar (Rusya, Venezuella,

Challenges for the Local Energy Elite, the Informal Economy and Stability, The Journal of Power Institutions in Post-Soviet Societies, No. 10, 2009.

${ }^{32}$ Joos Boonstra, "Georgia and Russia: A Short War with a Long Aftermath", FRIDE Comment, Ağustos 2008. 
Rusya Dış Politikası'nın Etkin Silahı:

Donmuş Çatışma Bölgeleri

Nikaragua, Tuvalu, Vanuatu ve Nauru gibi ülkeler dışında) ${ }^{33}$ BM

tarafindan tanınmamış olsalar da; Rusya, kendi çıkarlarını koruyabilmek ve yakın çevresinde etkinliğini sürdürebilmek amacıyla "tek taraflı" adımlar atabileceğini Abhazya ile Güney Osetya özelinde kanıtlamıştır. Rusya, bu adımının hukuken meşru olmadığını belirten Batılı aktörler özelinde ise, Kosova'nın hukuken tartışmalı olduğu ifade edilebilecek bağımsızlığının başta $\mathrm{ABD}$ olmak üzere birçok BM üyesi ülke tarafindan tanınmıș olmasını, kendi tezine/eylemine dayanak olarak göstermiștir. ${ }^{34}$ Her iki bölge de 2008 y1lından bu yana Rusya'nın askerî, siyasal ve ekonomik desteğine bağımlı olarak varlığını sürdürmektedir. Gürcistan hükümeti ise, bu durumu her ortamda Rusya'nın kendi içişlerine karışması ve hatta kendi topraklarını işgali olarak göstermesine karşın, bu hususta Rusya ile yeniden karşı karşıya gelmeyi göze alamamaktadır. Aynı zamanda, Tiflis'in ülkede yer alan ve ayrılıkçı bir karakter göstermesi "muhtemel" olan Samtskhe-Javakheti gibi bölgelerin ${ }^{35}$ Rusya desteğiyle bu yönde bir eylemlilik göstermesini istemediği için de fazlaca ileri gitmediği görülmektedir.

\subsection{Kırım ve Donbass Havzası}

Ukrayna, bağımsızlı̆ıından itibaren Rusya'nın kendi kontrolü altında tutmak istediği en önemli ülke olmuştur. Zira bu ülke Rusya'y1 güneyden çevrelemekte ve Karadeniz üzerinden dünyaya açılmakta olduğu için Moskova'nın kendi güvenliği ve gelecek projeksiyonları açısından çok önem verdiği bir noktada bulunmaktadır. Ayrıca Rusya'nın Karadeniz donanmasının en önemli üssü de Kırım'da yer almaktadır. ${ }^{36}$

33 “Abkhazia Recognised by Nauru”, The New York Times, 15 Aralı 2009, http://www.nytimes.com/2009/12/16/world/europe/16georgia.html (Erişim Tarihi: 26.07.2017).

${ }^{34}$ Anna V.Dolidze, "Can Kosovo Be a Precedent for South Ossetia and Abkhazia: Recognising Differences in Dynamics of Recognition", Cornell International Affairs Review, Vol. 2, No. 2, 2009.

${ }^{35}$ Nika Chitadze, "Samtskhe-Javakheti as a Potential Flash Point in Georgia: EthnicConfessional Composition and Integration Challenges", Caucasus International, Vol. 5, No. 3, 2015, pp. 101-115.

${ }^{36}$ Alan Yuhas and Raya Jalabi, "Ukraine Crisis: Why Russia Sees Crimea As Its Naval

Güvenlik

Stratejileri

Y11: 13

Sayı: 26 
Bunun yanı sıra, Ukrayna, Kiev Knezliği eliyle Rus kimliğinin oluşumunda birincil bir role sahiptir ve Slavofiller tarafindan Rusya'nın doğal ve ayrılmaz bir parçası olarak görülmektedir. ${ }^{37}$ Ukraynalılar da, gerek tarihsel, gerekse de etnik/ulusal ve kültürel bağlamda, Rus kimliğine en yakın toplum olarak görülmektedir. Ülkede Kırım ve Donbass Havzası başta olmak üzere önemli bir Rus asıllı ya da Rusça konuşan nüfus bulunması da Moskova'yı, Ukrayna'yı kontrol etme istekliliğine yönlendirmektedir. Rusya'nın "yakın çevresindeki" en büyük, en kalabalık ve coğrafi anlamda da en önemli ülke Ukrayna'dır.

$\mathrm{Bu}$ ülkenin milenyum sonrası yönünü Batı'ya çevirmek istemesi, $A B$ ve NATO üyeliğinin konuşulur hâle gelmesini beraberinde getirmiştir. Esasen AB ve NATO'nun Doğuya doğru yaptıkları birbirine paralel genişlemeler ekseninde Ukrayna en kritik önemi haiz ülke olmuştur. Zira bu ülkenin Batı'nın sistemsel hegemonyasına eklemlenmesi girişiminin Rusya tarafından tepkiyle karşılanacağ bilinmektedir. Bununla beraber, Ukrayna'nın yönünü Batı'ya çevirebilmek için 2004 yılında yaşanan Turuncu Devrim'e en büyük desteği Batılı aktörlerin verdiği görülmüştür. Hatta bu devrimin Batılı kurumlar, istihbarat örgütleri ve işadamları tarafından desteklendiğine ilişkin haberler de yayınlanmıştır. ${ }^{38}$ Turuncu Devrim sonrasında Ukrayna'nın Rusya'dan uzaklaşmaya çalışması ve AB ile NATO üyeliği hususlarını gündeme getirmesi, Rusya'nın bu ülke özelindeki "kozlarını" kullanmaya başlamasını beraberinde getirmiştir. ${ }^{39}$ Öncelikle "Bölgeler Partisi" ve Viktor Yanukovic ile temaslarını sıklaştıran Moskova, aynı zamanda Kırım ve Doğu Ukrayna' daki (Donbass) Rusya yanlılarının da Kiev'in dış politika söylem ve eylemlerini

Stronghold”, The Guardian, 7 Mart 2014, https://www.theguardian.com/world/2014/ mar/07/ukraine-russia-crimea-naval-base-tatars-explainer (Erişim Tarihi: 26.07.2017).

37 Taras Kuzio, "Soviet and Russian anti-(Ukrainian) Nationalism and ReStalinization", Communist and Post-Communist Studies, Vol. 30, 2015, pp. 1-13.

${ }^{38}$ Andrew Wilson, "Ukraine's Orange Revolution, NGOs and the Role of the West", Cambridge Review of International Affairs, Vol. 19, No. 1, 2006, pp. 21-32.

39 Taras Kuzio, "Ukraine's Relations with the West since the Orange Revolution", European Security, Vol. 21, No. 3, 2012, pp. 395-413. 
yönlendirebilmek için kullanılabileceğini görmüştür. Nitekim 203 Moskova'nın Kiev özelinde kullandığı başkaca enstrümanlar (enerji kesintileri, enerji fiyatlarının ciddi oranda yükseltilmesi, ticari kısıtlamalar, vb. $)^{40}$ ile birlikte, Batı'nın da Ukrayna'yı kendisine Güvenlik Stratejileri entegre etme hususunda yaşadığı kafa karışıklığı (özellikle 2008'de Gürcistan'da yaşananlardan sonra), Turuncu Devrim'in 2010 itibarıyla sona ermesine ve Rusya yanlısı Yanukovic'in Yuşçenko'ya karşı seçimleri kazanmasına neden olmuştur. ${ }^{41} \mathrm{Ne}$ var ki, bu seçimin ardından da ülkedeki Batı yanlıları ile Rusya yanlıları arasındaki mücadele sona ermemiştir. 2013 sonunda, Ukrayna Devlet Başkanı Yanukovic'in $\mathrm{AB}$ ile imzalanması beklenen "ortaklık antlaşmasını" imzalamayarak Rusya'ya yönelmesi, Batı yanlılarının sokaklara dökülerek Yanukovic'i devirmesine neden olmuştur. ${ }^{42}$ Yerine ise $A B$ ve NATO üyeliği yanlısı bir hükümet oluşturulmuştur. Ne var ki, Rusya, bu esnada harekete geçmiş ve hem Rusya'ya ait büyük bir donanma üssüne ev sahipliği yapan, hem de Rus çoğunluğun yaşadığı Kırım'ın Ukrayna'dan ayrılmasını ve bir referandumla kendisine bağlanmasını sağlamıştır. Böylece Rusya'da her daim tartışmalara konu olan ve SSCB döneminde Ukrayna'ya "hediye edilmiş" Kırım, yeniden Rusya'ya dönmüştür. Ne var ki, Kırım'ın Rusya'ya bağlanması sürecinde, her ne kadar Rusya kabul etmese de, Rus özel kuvvet mensupları ve milis güçleri etkin rol oynamıştır. Ayrıca özerk cumhuriyet statüsüne sahip olsa da, Kırım'ın “anayasal" anlamda Ukrayna'dan ayrılma yani "self-

\footnotetext{
${ }^{40}$ Andrew E.Kramer, "Russia Cuts off Gas to Ukraine in Cost Dispute", The New York Times, 2 Ocak 2006, http://www.nytimes.com/2006/01/02/world/europe/russia-cuts-off-gasto-ukraine-in-cost-dispute.html (Erişim Tarihi: 26.07.2017). Andrew E.Kramer, "Russia Cuts off Gas Deliveries to Ukraine", The New York Times, 1 Ocak 2009, http://www.nytimes.com/ 2009/01/02/world/europe/02gazprom.html (Erişim Tarihi: 26.07.2017).

${ }^{41}$ Mark Medish, "Ukraine's Presidential Elections-The End of the Orange Revolution", Carnegie Endowment Q\&A, 8 Şubat 2010, http://carnegieendowment. org/2010/02/08/ukraine-s-presidential-election-end-of-orange-revolution-pub-24818 (Erişim Tarihi: 26.07.2017).

${ }^{42}$ Serhiy Kudelia, "The House That Yanukovych Built", The Journal of Democracy, Vol. 25, No. 3, 2014, pp. 19-34.
} 


\section{Göktürk TÜYSÜZOĞLU}

204

Güvenlik

Stratejileri

Y1l: 13

Sayı: 26 determinasyon" hakkı bulunmadığı için, Rusya'ya bağlanma yönünde Kırım Parlamentosu'nun aldığ 1 kararın ve yapılan referandumun hem Ukrayna hükümeti, hem Batılı aktörler, hem de BM tarafindan tanınması söz konusu değildir. ${ }^{43}$ Ancak Rusya, yine Kosova örneği üzerinden ilerleyerek ve Kırım'daki Rusların can güvenliğini ileri sürerek ilhakını meşrulaştırmaya çalışmakta ve bu sürecin geri döndürülemez olduğunu açıkça belirtmektedir. Yani Moskova, Ukrayna'ya karşı bağımsızlık sonrası her daim bir koz olarak kullandığı ancak Turuncu Devrim sürecinde bölgede bulunan askerî üssün "kiralanması" ve kullanımı noktasında her an sorun yaşayabileceğini anladığı yarımadayı doğrudan ilhak ederek, bu kozunu kaybetmiştir. Ne var ki, Karadeniz'e açılım ve bölgede güç temerküzüne gitme anlamında da önemli bir adım atmıştır. Zira Rusya'nın bölgedeki donanma üssünü büyüttüğü ve güçlendirdiği de bilinmektedir. ${ }^{44} \mathrm{Bu}$ ilhak, özellikle Kırım Tatarları tarafından yaşanan hak gaspları ekseninde gündeme getirilmeye çalış1lsa $\mathrm{da},{ }^{45}$ Rusya ile Batı arasındaki gerginliğin tırmanması, Suriye'de yaşanan krizin küresel anlamda ön plana çıkması ve Donbass'daki gelişmeler nedeniyle fazlaca işlenmemektedir.

Donbass, Ukrayna'nın doğusuna/kuzeydoğusuna düşen, madencilik sektörünün gelişkin olduğu ve ülkenin ekonomik açıdan kalbi olarak bilinen bir havzadır. Donetsk, Luhansk ve Kharkiv, havzadaki en önemli şehirler olarak bilinmektedir. Donbass'da ciddi bir Rus kökenli nüfus yaşadığ 1 gibi, bölge halkının ekonomik ve sosyal açıdan daha çok Rusya ile temas içinde olduğu bilinmektedir. Ukrayna'da Kiev'in doğusu ile batısı arasında toplumsal kimlik ve siyasal anlayış bakımından belirgin bir farkl111k vardır ve bu farklı1ık, Donbass'ta Yanukovic'in

${ }^{43}$ Robin Geiss, "Russia's Annexation of Crimea: The Mills of International Law Grind Slowly but They Do Grind", International Law Studies, Vol. 91, No. 425, 2015, pp. 426-449.

44 "In Crimea, Russia Signals Military Resolve with New and Revamped Bases", Reuters, 1 Kasim 2016, http://www.reuters.com/investigates/special-report/russiacrimea (Erişim Tarihi: 26.07.2017).

${ }^{45}$ Filiz Tutku Aydın, "Crimean Tatars and Russia's Annexation of Crimea", Turkish Policy Quarterly, Vol. 13, No. 3, 2014, pp. 81-92. 
Rusya Dış Politikası'nın Etkin Silahı:

Donmuş Çatışma Bölgeleri

devrilmesi sonrası yaşanan gelişmeleri ve ayrılıkçı anlayışı da tetiklemiştir. ${ }^{46}$ Nitekim Kiev ve batısı, bugün itibarıyla genel olarak Batı (AB ve NATO) ile yakın ilişkiler kurulmasını ve Rusya'ya mesafeli yaklaşılmasını arzulayan, Ukranya kökenlilerin ve ülkedeki diğer toplumsal grupların (Leh, Macar, Rusyn) ağırlıklı olarak yaşadığı ve hem Ortodoks, hem de Katolik kiliselerinin varlığını koruduğu bir bölgedir. Kiev'in doğusunda ise, yine Ukranya kökenliler çoğunluğu oluştursa da, belli şehirlerde Ruslar önemli çoğunluğa ve etkiye sahiptir. Ayrıca bu bölgede Ukranyalılar ve Ruslar dışında, Kırım Tatarları hariç, önemli bir nüfus bulunmamaktadır. Moskova'daki Rus Ortodoks Kilisesi'nin ciddi nüfuza sahip olduğu bölge, öteden beri Rusya'nın doğal bir uzantısı gibi görülmektedir. Nüfusun büyük bir bölümü de kendisini Rusça ile ifade etmektedir.

Donbass Havzas1, Kırım'in Rusya tarafindan ilhak edilmesi sürecine paralel olarak Kiev'deki hükümetle anlaşmazlık içine girmiştir. Bölgeler Partisi ve Viktor Yanukovic'in oy tabanını oluşturan ve Rusya ile çok yakın temas içerisinde olan bölge, katıksız Batı yanlısı ve Rusya karşıtı Kiev Hükümeti'ni tanımamış ve bir süre sonra da Ukrayna Ordusu ile bölgede teşkilatlandırılan milis kuvvetleri arasında başta Donetsk ve Luhansk çevresinde olmak üzere kanlı çatışmalar yaşanmıştır. Bu çatışmalarda, 2017 yılının ortalarına dek 10 binin üzerinde asker, milis ve sivilin hayatını kaybettiği ifade edilmektedir. ${ }^{47}$ $\mathrm{Bu}$ çatışmalara paralel olarak, Rusya yanlısı ve "ayrılıkçı" bir karakter gösteren Donbass'taki aktörlerin Donetsk ve Luhansk şehirlerinde "de facto" halk cumhuriyetleri ilan ederek devletleşmeye çalıştıkları da görülmektedir. ${ }^{48}$ Minsk Süreci ile Batılı aktörler (Almanya ve Fransa)

\footnotetext{
${ }^{46}$ Ivan Katchanovski, "The Separatist War in Donbass: A Violent Break-up of Ukraine?", European Politics and Society, 2016, pp. 1-17.

${ }^{47}$ Damien Sharkov, "10.000 Ukrainians Killed So Far in Two-Year War", Newsweek, 31 Mayis 2016, http://www.newsweek.com/10000-ukrainians-killed-conflict-ukrainessecurity-council-465084 (Erişim Tarihi: 28.07.2017).

${ }^{48}$ Elise Giuliano, "The Origins of Separatism: Popular Grievances in Donetsk and Luhansk”, PONARS Eurasia Policy Memo, No. 396, 2015.
} 
ile Rusya tarafindan Ukrayna' daki krizin çözümüne ilişkin görüşmeler yapılmış ve silahlı çatışmalar genel itibarıyla durmuş olsa da, sorun çözülebilmiş değildir. ${ }^{49}$ Donbass'taki ayrılıkçı inisiyatif konjonktürel manada dondurulmuş durumdadır. $\mathrm{Bu}$ durum, bölgenin statüsünü "gevşek" bir federasyon ekseninde Ukrayna'ya bağlılık ekseninde kurgulamak isteyen Rusya'nın Kiev üzerindeki etkisini sürekli kılmaktadır. Nitekim Ukrayna hükümeti Kırım'ın Rusya tarafından ilhak edilmiş olmasını dahi tam manasıyla gündeme getiremeden Donbass'taki süreç çerçevesinde kurgulanan "donmuş çatışma bölgesi" sorunu ile karşı karşıya kalmıştır. AB'nin lider ülkeleri, NATO ve ABD Ukrayna'nın toprak bütünlüğüne destek verse de, bunun sağlanmas1 yönünde fiili bir adım atılamamaktadır. Zira Rusya Ukrayna'yı kendi arka bahçesi olarak gördüğü ve bu ülkenin dıș politika alternatiflerini kendi çıkarları çerçevesinde kurgulamaya çalıştığ 1 için, Donbass'taki aktörlere ekonomik, askerî ve siyasal destek vermeye devam etmektedir. Donetsk Halk Cumhuriyeti'nin Ukrayna'yı "başarısız devlet" olarak ilan ederek bu ülkenin ardılı bir "Malorossiya" Küçük Rusya adında bir devlet kurulacağını ilan etmesi; sorunun giderek içinden çıkılmaz bir hâl alacağını ortaya koymaktadır. ${ }^{50}$ Nitekim kurulmak istenen “Malorossiya”nın amaçlarına göz gezdirildiğinde, Rusya'nın merkezi bir rolde olduğu açıkça görülmektedir. Yani Rusya, Ukrayna özelinde önemli bir koza sahiptir ve bunu kullanmaya devam edecek gibi görünmektedir. Zira bu ülkedeki krizin Minsk Süreci'nin betimlediği "gevşek" bir federasyon ekseninde çözülmesi, taraflar arasındaki siyasal ve dış politikaya içkin farklılıklar nedeniyle orta vadede pek de mümkün görünmemektedir. $\mathrm{Bu}$ şekilde bulunacak bir çözüm dahi Rusya'nın Ukrayna'daki etkinliğinin devam etmesini de beraberinde getirecektir.

${ }^{49}$ Hrant Kostanyan and Stefan Meister, "Ukraine, Russia and the EU: Breaking the Deadlock in the Minsk Process", CEPS Working Document, No. 423, Haziran 2016.

50 Adam Taylor, "Ukrainian Separatists Claim to Have Created a New Country: Malorossiya, or "Little Russia", The Washington Post, 19 Temmuz 2017, https://www.washingtonpost.com/news/worldviews/wp/2017/07/19/ukrainianseparatists-claim-to-have-created-a-new-country-malorossiya-or-littlerussia/?utm_term=.bbb3a6fa273f (Erişim Tarihi: 28.07.2017). 
Rusya Dış Politikası'nın Etkin Silahı:

Donmuş Çatışma Bölgeleri

\subsection{Transdinyester}

Avrupa'nın doğusunda Ukrayna ile Romanya arasında konumlanan ve denize çıkışı olmayan eski bir Sovyet cumhuriyeti olan Moldova da Rusya'nın "donmuş çatışma bölgesi” kozuyla dış politika manevralarını manipüle edebildiği bir ülkedir. Nüfusunun önemli bir bölümü Rumen asıllı olmasına karşın, özellikle Dinyester nehrinin doğusundaki küçük bir toprak şeridinde ciddi bir Slav asıllı (Rus ve Ukraynalı) nüfus barındıran Moldova, aynı zamanda Gagavuz Türklerini de topraklarında barındıran "çok etnikli" bir ülke konumundadır. ${ }^{51}$ Zaten Moldovalı kimliği de SSCB döneminde yaratılmış bir anayasal üst kimliktir. ${ }^{52} \mathrm{Ne}$ var ki, SSCB döneminde Rus dili ve kültürü özelinde kurgulanmış ve Rumen çoğunluğun da bu çerçevede kabullenmiş olduğu "Moldovalı" kimliği, ülkenin bağımsızlığına paralel olarak, nüfusun çoğunluğunu oluşturan Rumen kimliğinin, dilinin ve kültürünün özelinde yeniden tanımlanmak istenmiştir. Hatta 1990'lı yılların başında, Moldova ile Romanya'nın birleşebileceğine dair iddialar dahi ortaya atılmıştır. ${ }^{53}$ Moldova kimliğinin Rumen ulusal kimliği özelinde yeniden tanımlanmaya çalışılması; Rusçanın resmî dil olmaktan çıkarılması; ve Rumen çoğunluğun devleti kendi talepleri doğrultusunda yöneterek SSCB döneminde ülke yönetiminde çok ciddi ağırlığa sahip Slav toplumunu "azınlık" statüsüne indirgeyebileceğine dair düşünceler ${ }^{54}$ Romanya ile Moldova'nın birleşebileceğine ilişkin endişeyle birleştiği noktada, büyük bölümü Dinyester'in doğusundaki sanayileşmiş (SSCB döneminde kurulmuş önemli bir demir-çelik sanayi üssü bulunmaktadır) toprak şeridinde yaşayan ve Rumen çoğunluktan Dinyester nehri

\footnotetext{
${ }^{51}$ Natalia Putina, "Real and Imagined Borders in the Multiethnic States-The Republic of Moldova Case", Eurolimes; Oradea, Vol. 17, 2014, pp. 107-122.

${ }^{52}$ Natalia Cojocaru, "Nationalism and Identity in Transnistria", Innovation, Vol. 19, No. 3-4, 2006, pp. 261-272.

${ }^{53}$ Michael Bird, “A Union Between Moldova and Romania: On the Cards?", EU Observer, 5 Mart 2015, https://euobserver.com/beyond-brussels/127824 (Erişim Tarihi: 28.07.2017).

${ }^{54}$ Marius Vahl and Michael Emerson, "Moldova and the Transnistrian Conflict", 2004, http://www.ecmi.de/fileadmin/downloads/publications/JEMIE/2004/1-2004Chapter4.pdf (Erişim Tarihi: 28.07.2017).
} 
208

Güvenlik Stratejileri

Y11: 13

Say1: 26

aracılığıyla ayrılan Slav asıllıların, Transdinyester (Dinyester ötesi) adı altında "ayrılıkçı" bir girişime yönelmelerine neden olmuştur. ${ }^{55}$

Prut ile Dinyester arasında kalan toprakları niteleyen ve tarihsel adı Besarabya olan bölgeye, SSCB döneminde Ukrayna'dan koparılarak eklenen ve Moldova adının siyasal/yönetimsel anlamda ilk kez kullanıldığ topraklar olarak bilinen Transdinyester, ${ }^{56}$ Moldova'nın geri kalanından toplumsal, ekonomik ve siyasal yönelim anlamında farklılaşmaktadır. Slavların çoğunluğu oluşturduğu, ekonomik gelişim düzeyi Moldova'nın geri kalanından çok daha yüksek, sanayileşmiş ve Rus dili ve kültürü üzerinden kendini ifade etmeyi tercih eden bölge, SSCB dönemindeki "özel günlerin" hâlen kutlandığ ${ }^{57}$ ve Rusya ile yakın ilişkiler kurulmasını arzulayan ve hatta Rusya'ya bağlanmayı hedefleyen bir görünümdedir. Moldova'nın bağımsızlığına paralel olarak yaşanan bir iç savaş sonrasında, bölgede konumlanmış SSCB (Rus) askerlerinin de verdiği destek ile "de facto" bağımsız bir yönetime kavuşan ve Rusya'nın arabuluculuğunda ulaşılan ateşkes ile adeta bir devlet inşasına girişen Transdinyester, bugün bir devletin sahip olmas1 gereken neredeyse tüm özellikleri haizdir. Bağımsız bir devlet olabilmek ya da "karadan sınırı olmamasına karşın", Rusya'ya bağlanmak isteyen Tiraspol, ${ }^{58} \mathrm{AB}$ ve NATO ile yakınlaşmak isteyen Moldova hükümetinden farklı bir dış politika anlayışına sahiptir. Bölge; ekonomik, ticari ve enerji ihtiyacının karşılanması anlamında Rusya'ya bağımlıdır. Barış gücü adı altında Dinyester çevresine konuşlanmış olan Rus askerleri de Transdinyester'in güvenliğinin sağlanması anlamında önemli role sahiptir. Transdinyester, Kırım'ın Rusya tarafindan ilhak edilmesi ve

${ }^{55}$ Nicu Popescu and Leonid Litra, "Transnistria: A Bottom-Up Solution", ECFR Policy Brief, No. 63, 2012.

${ }^{56}$ Monica Heintz, "Republic of Moldova versus Romania: The Cold War of National Identities", Journal of Political Science and International Relations, Vol. 2, No. 1, 2005, pp. 71-81.

57 Ala Svet, "Staging the Transnistrian Identity within the Heritage of Soviet Holidays", History and Anthropology, Vol. 24, No. 1, 2013, pp. 98-116.

58 John Beyer and Stefan Wolff, "Linkage and Leverage Effects on Moldova's Transnistria Problem", East European Politics, Vol. 32, No. 3, 2016, pp. 335-354. 
Rusya Dış Politikası'nın Etkin Silahı:

Donmuş Çatışma Bölgeleri

Ukrayna ile Rusya ilişkilerinin büyük çaplı bir krize saplanması sonrası, Rusya'ya bağlanabilmek adına Moskova'ya çağrıda bulunmuştur. ${ }^{59}$ Zira Odessa Limanı üzerinden ticari anlamda "nefes alabilen" Transdinyester, Rusya ile Ukrayna'nın arasının açılması ve Ukrayna'nın 2005 yılından bu yana Tiraspol ile ekonomik ve ticari ilişkilerini kesmesi yönünde $\mathrm{AB}$ tarafindan baskılanması nedeniyle, zor durumda kalmıştır. ${ }^{60} \mathrm{Ne}$ var ki, kendi özelinde nitelenecek yeni bir bölgesel kriz istemeyen ve Moldova'nın dış politika hamlelerini Transdinyester özelindeki ağırlığ 1 ekseninde kontrol edebilmesini önemli bir "koz" olarak gören Rusya, Tiraspol'ün "ilhak" talebine olumlu yanıt vermemiştir. Kuşkusuzi bölgenin Rusya ile karadan sınırının olmaması da coğrafi anlamda önemli bir rol oynamıştır.

Rusya, Moldova'nın Batı yöneliminin ayırdındadır. Nitekim ülkede $\mathrm{AB}$ yanlısı bir hükümet iktidardadır. Doğu Avrupa özelinde daha fazla gücünü yitirmek istemeyen Rusya; Beyaz Rusya, Moldova ve Ukrayna'yı vazgeçilemez ülkeler olarak görmekte ve onların NATO ve AB şemsiyesi altına girmesini istememektedir. Avrupa'nın en fakir ülkesi olarak bilinen ve AB'yle yakınlaşarak bu durumdan kurtulabileceğini düşünen Kişinev, Rusya'nın kendisi üzerindeki siyasal/askerî baskısını da NATO aracılığıyla kırabileceğine inanmaktadır. Ancak Rusya da bu durumun farkındadır ve ülkedeki çeşitli siyasal parti ve gruplarla temas kurmaya çalışmaktadır. Hem Batılı aktörlere Moldova'nın $A B$ ve NATO üyesi olarak görülmemesi yönünde bask1 yapmakta, hem de Transdinyester'deki "fiili" egemenliğin devam etmesini sağlayarak Moldova'yı toprak bütünlüğüne ilişkin büyük çaplı bir kriz ve belirsizlik ile karşı karşıya bırakmaktadır. Ülkede AB yanlısı bir hükümet iktidarda olmasına karşın, son yapılan devlet başkanlığı

${ }^{59}$ Damien Sharkov, "Moldova's Transnistrian Separatists Urge Russia Annexation", Newsweek, 9 Eylül 2016, http://www.newsweek.com/moldovas-transnistrianseparatists-call-join-russia-496931 (Erişim Tarihi: 28.07.2017).

${ }^{60}$ Daniela Peterka-Benton, "Arms Trafficking in Transnistria: A European Security Threat?”, Journal of Applied Security Research, Vol. 7, No. 1, 2012, pp. 71-92. 

seçimlerini Rusya yanlısı olarak bilinen Igor Dodon'un kazanması, ${ }^{61}$ ülkedeki kafa karışıklığını gösteren açık bir gelişmedir. Yani Moskova, Transdinyester özelindeki etkinliği ile birlikte Moldova'nın siyasal dengesini sarsabilmekte ve bu ülkenin dış politika yaklaşımını ciddi bir belirsizliğe iterek $\mathrm{AB}$ ve NATO'nun Kişinev üzerindeki etkinliğini azaltabilmektedir.

\section{Sonuç}

SSCB'nin dağılması sonrası kaybettiği "küresel" rolünü yeniden kazanabilmeyi amaçlayan Rusya, bu çerçevede "yakın çevresini" oluşturan, özelde eski Sovyet toprakları, genelde ise Avrasya anakarası bağlamında bölgesel bir hegemon olabilmeyi hedeflemektedir. Bu hedef, Moskova'nın altını özenle çizdiği sistemsel çok kutupluluk anlayışına da uygundur. Rusya, Avrasyacı düşünce ekseninde betimlenen Avrasya medeniyetinin merkezi haline gelerek, bu geniş coğrafyada yaşayan farklı etnik/dinsel grupların siyasal, askerî ve ekonomik anlamda "kıblesi" olmayı planlamaktadır. Bu plan doğrultusunda da "arka bahçesi" olarak gördüğü eski Sovyet cumhuriyetlerinin yüzünü Batı'ya değil, Moskova'ya döndürmesi gerektiğini gören Rusya; Doğu Avrupa ve Güney Kafkasya'da NATO ve AB genişleme dalgaları sebebiyle Batı'yla doğrudan karşı karşıya gelmektedir. Orta Asya'da ise Çin'le eşgüdüm içinde hareket etmekte ve "çok kutupluluk" ile Batı hegemonyasına karş1 ortak bir duruş sergiledikleri Pekin ile orta vadede sorun yaşamak istememektedir. Rusya, yakın çevresi ve Avrasya özelinde oluşturmak istediği bölgesel hegemonyayı kurumsallaştırabilmek amaciyla da Avrasya Ekonomik İşbirliği Örgütü ve onun askerî uzantıs1 olarak betimlenebilecek Kolektif Güvenlik Antlaşması Örgütü'nü etkinleştirmeye çalışmaktadır.

Rusya, eski Sovyet cumhuriyetlerine yönelik olarak kullanabileceği bir "yumuşak güç" avantajına sahip değildir. Nitekim ülkenin sosyo-

61 "Moldova Government Expels Five Russian Diplomats, President Furious", Reuters, 29 Mayls 2017, http://www.reuters.com/article/us-moldova-russia-idUSKBN18P1QP (Erişim Tarihi: 28.07.2017). 
ekonomik refah düzeyi yüksek değildir ve demokratik çoğulculuk ile insan haklarına riayet etme konusunda Batı'nın sahip olduğu standartların oldukça gerisindedir. Otoriter bir yönetim anlayışının kurumsallaştığı ve Çarlık ile Sovyet geçmişlerinden dolayı yeni bağımsız ülkelerin genel itibarıyla "hazzetmediği" Rusya, bu minvalde sahip olduğu başkaca avantajları harekete geçirerek yakın çevresindeki ülkelerin dış politika hamlelerini ya da stratejilerini yönlendirme gayretindedir. Batılı aktörlere nazaran sahip olduğu coğrafi avantaj ve bilgi birikiminin yanı sıra; askerî, siyasal ve özellikle enerji ile ticaret bağlamlı cezalandırma tedbirlerini, yani "sert güç" unsurlarını kullanan Rusya, yakın çevresindeki eski Sovyet cumhuriyetlerini etkileme ve yönlendirme kapasitesini korumaktadır. Moskova'nın son dönemde özellikle kullandığı siyasal yönlendirme/manipülasyon unsuru ise, eski Sovyet cumhuriyetlerinin bağımsızlıklarına paralel olarak genel itibarıyla etnik/dinsel farkl1lıklar ve rekabet özelinde beliren ve ortaya çıkmasında özellikle SSCB'nin büyük rolü olan "donmuş çatışma bölgeleri"dir. Azerbaycan, Gürcistan ve Moldova ile Ukrayna gibi topraklarında donmuş çatışma bölgeleri barındıran ve aynı zamanda Rusya'nın bölgesel hegemonya girişimine karşıt bir duruş sergileme ihtimali bulunan ya da sergilemeye çalışan ülkeler; Moskova tarafindan gerek ekonomik ve siyasal baskılar, gerekse de donmuş çatışma bölgelerinin statüsü ve geleceğine ilişkin kafa karışıklığ1 yaratan hamlelerde bulunularak kullanılmaktadır. Böylece bu sorunların yaşandığı ülkelerin özellikle NATO üyeliğgi, AB ile yakınlaşma süreçleri ve Rusya karşıtı manevralarda bulunma istekliliği baskılanmaya çalışılmaktadır. Yani bu bölgeler, Rusya dış politikasına eklemlenmiş birer "koz" niteliği kazanmıştır. Rusya, bu kozlarını Gürcistan (Abhazya ve Güney Osetya'nın bağımsızlığının tanınması) ve Ukrayna özelinde (Kırım'ın ilhakı) görüldüğü üzere zaman zaman kullanmak zorunda kalırken; bazen de Dağlık Karabağ, Donbass Havzası ve Transdinyester örneklerinde görüldüğü üzere, geleceğe içkin birer koz olarak elinde tutmaya devam etmektedir.

$\mathrm{Bu}$ çerçevede, Rusya'nın, eski Sovyet coğrafyasındaki tarihsel süreklilik içinde belirmiş ya da belirme ihtimali bulunan donmuş çatışma bölgeleri gerçekliğini kendi bölgesel hegemonya inşası sürecinde aktif bir 
212

Güvenlik

Stratejileri

Y1l: 13

Sayı: 26

şekilde kullanacağı anlaşılmaktadır. Her ne kadar kendi içinde de benzer bir sorunla karşı karşıya kalma ihtimali bulunsa da, Moskova, bu tehdidin kendisi açısından çok da gerçekçi olmadığını Çeçenistan'da elde ettiği başarıya binaen değerlendiriyor olmalıdır. Bundan sonraki süreçte, Avrasya geneli ve eski Sovyet cumhuriyetleri özelinde belirecek donmuş çatışma bölgeleri özelinde de Rusya merkezi bir konuma sahip olacak ve bu sorunları kendisi lehinde kullanabilecektir.

\section{Summary}

Russia aims to regain its "global" role by becoming a regional hegemony especially in the context of the former Soviet territories and, in general, the Eurasian mainland which constitute its "immediate surrounding". This goal is also suitable for the concept of systemic multi-polarity that Moscow carefully draws attention. Russia is the center of the Eurasian civilization, which is depicted on the axis of Eurasian thought and Moscow plans to become "kiblah" of different ethnic/religious groups living at this vast geography in political, military, and economic sense.

Russia thinks that the former Soviet republics, which Moscow considers as its "backyard", should be turned to Moscow, not to the West. For this reason, in Eastern Europe and the South Caucasus, Russia is directly confronted with the West due to NATO and EU enlargement. In Central Asia, Russia acts in coordination with China, and they do not want to have problems where they stand in a common position against Western hegemony. Russia is also trying to activate the Collective Security Treaty Organization, which can be described as the Eurasian Economic Cooperation Organization's military extension, in order to institutionalize the regional hegemony that it wants to establish in Eurasia.

Russia does not have the "soft power" advantage which it can use for the former Soviet republics. Indeed, the socio-economic prosperity of the country is not high and is far behind the standards of the West for democratic pluralism and respect for human rights. Russia, for which an authoritarian political approach has been institutionalized and which is generally "not liked" by new independent countries due to 
Rusya Dış Politikası'nın Etkin Silahı:

Donmuş Çatışma Bölgeleri

Tsarist and Soviet past, is actively directing the foreign policy moves or 213 strategies of neighboring countries by activating other advantages it possesses. Using geographical advantage and knowledge as compared to Western actors, as well as its military, political, and especially energy-related punitive measures as "hard power" elements, Russia maintains the capacity to influence and direct the former Soviet republics in its immediate vicinity. The political orientation /manipulation element that Moscow has recently used in particular is the "frozen conflict zones", which, in parallel with the independence of the former Soviet republics, are characterized by ethnic/religious differences and competition in particular. Countries with frozen conflict zones like Azerbaijan, Georgia, Moldova, and Ukraine are used by Moscow to create confusion about the status and future of both economic and political pressures, as well as the status of frozen conflict zones. The reason for this is that these countries are likely to exhibit a stand against Russia's regional hegemony initiative. Thus, the countries in which these problems are experienced are tried to be suppressed by Russia because of the probability of NATO membership, the process of rapprochement with the EU, and the willingness to hold anti-Russian maneuvers. In other words, frozen conflict zones have gained the character of a leverage that could be used by Russia. While Russia has been forced to use these trumps from time to time in Georgia (recognizing the independence of Abkhazia and South Ossetia) and Ukraine (annexation of the Crimea), occasionally, as in Nagorno-Karabakh, Donbass Basin, and Transnistria examples, it continue to hold some others for future.

It is understood in this framework that Russia will actively use the frozen conflict zones that appeared at the former Soviet geography in constructing its own regional hegemony. Although there is a possibility of facing a similar problem in its own country, Moscow should be assessing the success achieved in Chechnya that this threat is not very realistic for itself. In the following period, Russia will have a central position in frozen conflict zones that will be specific to the former Soviet republics and it will be able to use these problems in its own favor. 


\section{4}

Güvenlik

Stratejileri

Y11: 13

Say1: 26

\section{Kaynakça}

Kitaplar

KAZIMIROV, Vladimir, Peace to Karabakh: Russia's Mediation in the Settlement of the Nagorno-Karabakh Conflict, Moscow: VES MIR Publishers, 2014.

SAMMUT, Dennis and Nikola Cvetkovski, Confidence Building Matters: The Georgia-South Ossetia Conflict, London: VERTIC Papers, 1996.

\section{Makaleler ve Kitap Bölümleri}

ABİLOV, Shamkhal and Ismayil Isayev, "The Consequences of the Nagorno-Karabakh War for Azerbaijan and the Undeniable Reality of Khojaly Massacre", Polish Political Science Yearbook, Vol. 45, 2016, pp. 291-303.

ASLANLI, Araz, "20.Yüzyılın Başlarında ve Sonlarında Güney Kafkasya'da Ermeni Sorunu: Karabağ Sorunu Örneği”, Yeni Türkiye, No. 60, 2014, pp. 1-24.

AYDIN, Filiz Tutku, "Crimean Tatars and Russia's Annexation of Crimea", Turkish Policy Quarterly, Vol. 13, No. 3, 2014, pp. 81-92. BAŞKAN, Argun, "Kafkasya'da Bütünleşme ve Dağılma Döngüleri İçinde Gürcüler, Zanlar (Megreller ve Lazlar) ve Svanlar", Karadeniz Araştırmaları, No. 30, 2011, pp. 15-41.

BEYER, John and Stefan Wolff, "Linkage and Leverage Effects on Moldova's Transnistria Problem", East European Politics, Vol. 32, No. 3, 2016, pp. 335-354.

BIRD, Michael, "A Union Between Moldova and Romania: On the Cards?", EU Observer, 5 Mart 2015, https://euobserver.com/beyondbrussels/127824 (Erişim Tarihi: 28.07.2017).

BOWKER, Mike, "Russia and Chechnya: the Issue of Secession", Nations and Nationalism, Vol. 10, No. 4, 2004, pp. 461-478.

CHITADZE, Nika, "Samtskhe-Javakheti As a Potential Flash Point in Georgia: Ethnic-Confessional Composition and Integration Challenges", Caucasus International, Vol. 5, No. 3, 2015, pp. 101-115.

COJOCARU, Natalia, "Nationalism and Identity in Transnistria", Innovation, Vol. 19, No. 3-4, 2006, pp. 261-272. 
DOLIDZE, Anna V., "Can Kosovo Be a Precedent for South Ossetia and Abkhazia: Recognising Differences in Dynamics of Recognition", Cornell International Affairs Review, Vol. 2, No. 2, 2009.

ELLISON, Brian J., "Russian Grand Strategy in the South Ossetia War", Demokratizatsiya, Vol. 19, No. 4, 2011, pp. 343-366. GEISS, Robin, "Russia's Annexation of Crimea: The Mills of International Law Grind Slowly But They Do Grind", International Law Studies, Vol. 91, No. 425, 2015, pp. 426-449.

GURBANOV, Ilgar, "Is Armenia a Strategic Satellite of Russia?", New Eastern Europe, Vol. 8, No. 3, 2013, pp. 82-88.

HEINTZ, Monica, "Republic of Moldova versus Romania: The Cold War of National Identities", Journal of Political Science and International Relations, Vol. 2, No. 1, 2005, pp. 71-81.

HUGHES, James, "Managing Secession Potential in the Russian Federation", Regional \& Federal Studies, Vol. 11, No. 3, 2001, pp. 36-68. HUGHES, James, "Managing Secession Potential in the Russian Federation", Regional \& Federal Studies, Vol. 11, No. 3, 2001, pp. 36-68. KATCHANOVSKI, Ivan, "The Separatist War in Donbass: A Violent Break-up of Ukraine?", European Politics and Society, 2016, pp. 1-17.

KHAZANOV, Anatoly M., "A State without a Nation? Russia after Empire", The Nation State in Question, T.V.Paul, G.John Ikenberry and John A.Hall (ed.), New Jersey: Princeton University Press, 2003.

KOLOSSOV, Vladimir and John O'Loughlin, "Violence in the Caucasus: Economic Insecurities and Migration in the De Facto States of Abkhazia and South Ossetia", Eurasian Geography and Economics, Vol. 52, No. 5, 2011, pp. 1-30.

KUDELIA, Serhiy, "The House That Yanukovych Built", The Journal of Democracy, Vol. 25, No. 3, 2014, pp. 19-34.

KUZIO, Taras, "Soviet and Russian anti-(Ukrainian) Nationalism and Re-Stalinization", Communist and Post-Communist Studies, Vol. 30, 2015, pp. 1-13.

KUZIO, Taras, "Ukraine's Relations With the West Since the Orange Revolution”, European Security, Vol. 21, No. 3, 2012, pp. 395-413. MOROZOVA, Natalia, "Geopolitics, Eurasianism and Russian Foreign Policy Under Putin”, Geopolitics, Vol. 14, No. 4, 2009, pp. 667-686. 
ORTTUNG, Robert and Christopher Walker, "Putin's Frozen Conflicts", Foreign Policy, 13 Şubat 2015, http://foreignpolicy.com/ 2015/02/13/putins-frozen-conflicts (Erişim Tarihi: 24.07.2017).

Y11: 13 OVERLAND, Indra, "The Closure of the Russian Military Base at Akhalkalaki: Challenges for the Local Energy Elite, the Informal Economy and Stability", The Journal of Power Institutions in PostSoviet Societies, No. 10, 2009.

PETERKA-BENTON, Daniela, "Arms Trafficking in Transnistria: A European Security Threat?", Journal of Applied Security Research, Vol. 7, No. 1, 2012, pp. 71-92.

PUTINA, Natalia, "Real and Imagined Borders in the Multiethnic States-The Republic of Moldova Case", Eurolimes; Oradea, Vol. 17, 2014, pp. 107-122.

SERGUNIN, Alexander and Leonid Karabeshkin, "Understanding Russia's Soft Power Strategy", Politics, Vol. 35, No. 3-4, 2015, pp. 347-363.

SHEKHOVTSOV, Anton, "Aleksandr Dugin's Neo-Eurasianism: The New Right a la Russé", Religion Compass, Vol. 3, No. 4, 2009, pp. 697-716.

SHLAPENTOKH, Dmitry, "Islam and Orthodox Russia: From Eurasianism to Islamism", Communist and Post-Communist Studies, Vol. 41, Mart 2008, pp. 27-46.

STARR, S.Frederick and Svante E. Cornell, "Tactics and Instruments in Putin's Grand Strategy", Putin's Grand Strategy: The Eurasian Union and Its Discontents, S. Frederick Starr and Svante E. Cornell (ed.), Washington: Silk Road Studies, 2014, pp. 59-81.

SVET, Ala, "Staging the Transnistrian Identity within the Heritage of Soviet Holidays", History and Anthropology, Vol. 24, No. 1, 2013, pp. 98-116.

TURNER, Susan, "Russia, China and a Multipolar World Order: The Danger in the Undefined", Asian Perspective, Vol. 33, No. 1, 2009, pp. 159-184.

UMLAND, Andreas, "Post-Soviet Neo-Eurasianism, the Putin System and the Contemporary European Extreme Right", Perspectives on Politics, Vol. 15, No. 2, 2017, pp. 465-476. 
Rusya Dış Politikası'nın Etkin Silahı:

Donmuş Çatışma Bölgeleri

VENDINA, Olga I., Vitali S. Belozerov and Andrew Gustafson, "The Wars in Chechnya and Their Effects on Neighboring Regions", Eurasian Geography and Economics, Vol. 48, No. 2, 2007, pp. 178-201.

Güvenlik Stratejileri WILSON, Andrew, "Ukraine's Orange Revolution, NGOs and the Y11: 13 Role of the West", Cambridge Review of International Affairs, Vol. 19, No. 1, 2006, pp. 21-32.

\section{Raporlar}

"Abkhazia Recognised by Nauru", The New York Times, 15 Aralık 2009, http://www.nytimes.com/2009/12/16/world/europe/ 16georgia.html (Erişim Tarihi: 26.07.2017).

"In Crimea, Russia Signals Military Resolve with New and Revamped Bases", Reuters, 1 Kasim 2016, http://www.reuters.com/investigates/ special-report/russia-crimea (Erişim Tarihi: 26.07.2017).

"Moldova Government Expels Five Russian Diplomats, President Furious", Reuters, 29 May1s 2017, http://www.reuters.com/article/usmoldova-russia-idUSKBN18P1QP (Erişim Tarihi: 28.07.2017).

"Rusya'dan Ermenistan'la Ortak Orduya Onay Çıktı", Kırım Haber Ajansı (QHA), 16 Temmuz 2017, http://qha.com.ua/tr/askeri-guvenlik/ rusya-dan-ermenistan-la-ortak-orduya-onay-cikti/157530 (Erişim Tarihi: 25.07.2017).

AYDINTAŞBAŞ, Aslı and Kemal Kirişci, "The United States and Turkey: Friends, Enemies or Only Interests", Brookings Institute Turkey Project Policy Paper, No. 12, Nisan 2017.

BOONSTRA, Jos, "Georgia and Russia: A Short War with a Long Aftermath", FRIDE Comment, Ağustos 2008.

GIULIANO, Elise, "The Origins of Separatism: Popular Grievances in Donetsk and Luhansk", PONARS Eurasia Policy Memo, No. 396, 2015.

GREENE, James, "Russian Responses to NATO and EU: Enlargement and Outreach", Chatham House Russia and Eurasia Programme Briefing Paper, Haziran 2012.

JUHAS, Alan and Raya Jalabi, "Ukraine Crisis: Why Russia Sees Crimea as Its Naval Stronghold", The Guardian, 7 Mart 2014, https://www.theguardian.com/world/2014/mar/07/ukraine-russiacrimea-naval-base-tatars-explainer (Erişim Tarihi: 26.07.2017). 

EU: Breaking the Deadlock in the Minsk Process", CEPS Working Document, No. 423, Haziran 2016.

Y11: 13 KRAMER, Andrew E., "Russia Cuts off Gas Deliveries to Ukraine", The New York Times, 1 Ocak 2009, http://www.nytimes.com/2009/ 01/02/world/europe/02gazprom.html (Erişim Tarihi: 26.07.2017).

KRAMER, Andrew E., "Russia Cuts off Gas to Ukraine in Cost Dispute", The New York Times, 2 Ocak 2006, http://www.nytimes. com/2006/01/02/world/europe/russia-cuts-off-gas-to-ukraine-in-costdispute.html (Erişim Tarihi: 26.07.2017).

LARUELLE, Marléné, "The Russian World: Russia's Soft Power and Geopolitical Imagination”, CGI-Center on Global Interests, Mayıs 2015. MEDISH, Mark, "Ukraine's Presidential Elections-The End of the Orange Revolution", Carnegie Endowment Q\&A, 8 Şubat 2010, http://carnegieendowment.org/2010/02/08/ukraine-s-presidential-election -end-of-orange-revolution-pub-24818 (Erişim Tarihi: 26.07.2017).

MERRY, E.Wayne, "Dealing with the Ukrainian Crisis: Transatlantic Strategy Dilemmas", IAI Working Papers, Vol. 15, No. 51, 2015. POPESCU, Nicu and Leonid Litra, "Transnistria: A Bottom-Up Solution", ECFR Policy Brief, No. 63, 2012.

SHARKOV, Damien, "10.000 Ukrainians Killed So Far in Two-Year War", Newsweek, 31 Mayis 2016, http://www.newsweek.com/10000-ukrainianskilled-conflict-ukraines-security-council-465084 (Erişim Tarihi: 28.07.2017).

SHARKOV, Damien, "Moldova's Transnistrian Separatists Urge Russia Annexation", Newsweek, 9 Eylül 2016, http://www.newsweek. com/moldovas-transnistrian-separatists-call-join-russia-496931 (Erişim Tarihi: 28.07.2017).

STACK, Liam and Karen Zraick, "Frozen Zones: How Russia Maintains Influence in the Post Cold War Era", The New York Times, 14 Ekim 2015, https://www.nytimes.com/interactive/2015/10/14/ world/europe/ russia -frozen-zones-syria.html (Erişim Tarihi: 24.07.2017).

TAYLOR, Adam, "Ukrainian Separatists Claim to Have Created a New Country: Malorossiya, or 'Little Russia"', The Washington Post, 19 Temmuz 2017, https://www.washingtonpost.com/news/worldviews/wp/ 
2017/07/19/ukrainian-separatists-claim-to-have-created-a-new-country -malorossiya-or-little-russia/?utm_term=.bbb3a6fa273f (Erişim Tarihi: 28.07.2017).

TRENIN, Dmitri V., "The Forgotten War: Chechnya and Russia's Future", Carnegie Endowment Policy Brief, No. 28, Kasım 2003.

ZASZTOWT, Konrad, "Armenia in the Eurasian Economic Union: Challenges for the EU”, PISM Bulletin, No. 22 (754), 2015.

\section{Tezler}

POHL, Brittany A., "Frozen Conflicts, De Facto States and Enduring Interests in the Russian Near Abroad", MSU Graduate Theses, No. 3039, 2016.

\section{Internet Siteleri}

VAHL, Marius and Michael Emerson, "Moldova and the Transnistrian Conflict", 2004, http://www.ecmi.de/fileadmin/downloads/publications /JEMIE/2004/1-2004Chapter4.pdf (Erişim Tarihi: 28.07.2017). 

